\title{
The Application of POA-based Reciprocal Teaching Model in Chinese Senior High School English Writing Class*
}

\author{
Guobing Liu \\ Faculty of International Studies, Henan Normal University, Xinxiang, China \\ Hui Cao \\ Faculty of International Studies, Henan Normal University, Xinxiang, China
}

\begin{abstract}
In order to effectively improve the efficiency of English writing class in Chinese senior high school, this paper explores the effectiveness of POA-based reciprocal teaching model, i.e. Production-based reciprocal teaching (PBRT). The research instruments include classroom observation, interview and test. It has been found: (1) PBRT has a positive impact on Chinese senior high school students' interests in English writing. (2) PBRT can significantly improve students' writing abilities. (3) The application of PBRT in writing class need build a teacher-student community. The teachers should design situational teaching activities in class and promote their knowledge application abilities. There are few researches on reciprocal teaching based on POA in senior high school. This study aims to provide new ideas for improving the efficiency of English writing class in Chinese senior high school.
\end{abstract}

Index Terms-POA, reciprocal teaching, Chinese senior high school, English writing

\section{INTRODUCTION}

Proverbially, the improvement of writing ability is a difficult issue in English teaching, which is compactly related to students' vocabulary, grammar and discourse analysis ability. Students need promote the internalization of target language knowledge and master the usage of English words, phrases, grammars and sentence patterns. The cultivation of writing ability is a gradual process, which depends on the guidance of teachers and the participation of students.

POA is a teaching theory with Chinese characteristics put forward by Professor Wen in recent years. Based the researches on students' production, Wen (2015) explored and proposed a new theoretical method of classroom teaching based on the current situation of education and teaching in China - Production-Oriented Approach (POA). POA aims at improving the level of English teaching and language output, which tries to solve the current situation of English teaching that pays more attention to input than output. Since the POA was put forward, researchers have done a lot of related researches on it. Under the background of the new area, this theory has formed an innovative foreign language theoretical system with Chinese characteristics (Yang, 2018). Some academic studies have shown that POA is targeted at the researches of advanced English Learners and most POA studies have been applied to college English teaching. Zhang (2017) conducted an action research to explore the feasibility and effectiveness of POA for college English teaching. POA is applied in teaching, which has a guiding significance for all aspects of practical teaching. On a macro level, He (2020) made an in-depth study of curriculum design based on the POA. In terms of unit teaching design, Tang (2020) took the intensive reading course for English majors as a case and compared POA and TBLT (Task-based Language Teaching) in detail.

However, POA theory combined with reciprocal teaching mode is rarely applied in English writing classes in Chinese senior high school. This study follows the teaching process of POA theory - motivating-enabling-assessment, and applies reciprocal teaching to senior high school writing class. Researcher focuses on students' production and explores the effectiveness of production-based reciprocal teaching (PBRT). Two rounds of action researches which have conducted prove PBRT is suitable for English writing teaching in Chinese senior high school.

\section{LITERATURE REVIEW}

\section{A. The Concept of Production}

Swain (1985) believed that successful foreign language learners needed not only to be exposed to a large amount of comprehensible input, but also to produce comprehensible output. Krashen (1985) attempted to explain how the learner acquired a second language and proposed input hypothesis. Since the input hypothesis and output hypothesis were

\footnotetext{
* This research was supported financially in part by the Research Project of Teaching Reform in Henan Teachers' Education "The OBE-Based Innovation of English Writing Teaching Model in Senior High Schools".
} 
proposed and introduced into China, many Chinese scholars have applied these two hypotheses to English teaching. Moreover, they have made many research achievements. On this basis, Wen (2008) put forward the "production-driven hypothesis", which was the prototype of POA. In 2014, the "production-driven hypothesis" was revised to "production driven \& input driven hypotheses" (Wen, 2014). Wen (2015) put forward the theoretical system of POA, which was mainly aimed at middle and advanced foreign language learners. "Production" emphasizes both the process and the result. The teaching philosophy of POA includes: learning center theory, learning and application theory and holistic education theory. Wen (2020) further explained the teaching process of POA, which was motivating-enabling-assessment. The production task of unit is divided into several small parts. The teacher should first decompose the production task and students need to complete. The teaching for each production task follows the teaching process. After several small production tasks are successfully completed, the completion of unit production tasks will come naturally.

\section{B. The Concept of Reciprocal Teaching}

Palinsar (1984) proposed a teaching method aimed at improving students' reading comprehension and self-learning ability. It is a teaching mode developed on the basis of scaffolding instruction. Scholars have not yet made an agreement on the definition of "reciprocal teaching". Reciprocal teaching is a teaching method of equal communication and independent interaction between teachers' teaching and students' learning, which centers on a certain problem or subject on the multi-point teaching platform. It has important educational value. Reciprocal teaching refers to the cooperative relationship of communication and interaction between teachers and students by using rationally diversified teaching methods. So students could complete the transformation from curiousness to learning. Li (2003) considered reciprocal teaching actually was a transformation of modern teaching methods from the teacher-centered traditional teaching methods to the student-centered. The teaching method is to realize that the main body of learning is the student, which gives full initiative of learning in class. Reciprocal teaching is a kind of student-centered teaching thought. This is a platform for students and teachers to communicate freely.

\section{Previous Studies on POA}

The domestic researches of POA not only stay in macroscopic teaching, but focus on micro teaching steps. First of all, Wen \& Sun (2020) put forward five elements that were drive scenes, namely topic, purpose, identity and occasion. Secondly, through the analysis of examples, the design criteria of facilitating links were put forward, named precision, gradualness and diversity. Finally, combined with practical facts, Sun (2020) proposed a new evaluation form - TSCA (Teacher-Student Collaborative Assessment) in the evaluation stage, with the purpose of promoting learning through evaluation. The profound interpretation of the above teaching process is worth each teacher's deep thinking. Teachers should use the latest theories to deepen their own teaching thoughts and guide their own teaching design.

The researches of POA in foreign countries mainly focus on four aspects: comprehensive evaluation, research direction suggestion, novice teachers and practical application. Some scholars have made a comprehensive evaluation of POA. Rod Ellis (2017) highlighted the impact of POA. He thought the theory had a strong theoretical basis, but there were limitations in the completion of evaluation, so we should devote ourselves to the design and implementation of teacher training courses. A wide range of live actions can be added to the end of the unit to create an existing text that can be used by students. There are some suggestions for improvement of POA through practical researches. Alister Cumming (2017), a professor at the University of Toronto, suggested three things. First of all, we should expand the teaching reform for the situation of additional education. Secondly, we must guarantee English beginners to carry out related tests. Thirdly, future researches on POA seem to be prepared for second language acquisition. The theory has made an important contribution. In the practical teaching application of POA, some scholars put forward relevant requirements for novice teachers. According to Charlene Polio (2017) who analyzed the Outcome-oriented Method from the perspective of novice teachers, there is no one method that fits all circumstances and teachers should be allowed to modify their teaching curriculum. At the same time, POA provides a good starting point for the challenges faced by novice teachers.

Based on the reality, POA can solve the problems in teaching practice more effectively. Therefore, this research combines the POA to solve the problem of Chinese senior high school students' writing difficulties and improve their writing abilities. Through two rounds of action researches, the researcher tests PBRT's effectiveness in practical teaching and explores the improvement of class efficiency.

\section{Previous Studies on Reciprocal Teaching}

Since reciprocal teaching was put forward, scholars have studied it from different aspects, such as innovation, science and technology. The emergence of reciprocal teaching is accompanied by disciplinary tools, among which the reciprocal whiteboard is the most influential. The interactive whiteboard, with its powerful interactive function and flexible subject tools, has triggered a new round of theoretical and practical research on the curriculum reform of basic education. Yang \& Ren (2014) deeply analyzed the current situation of interactive electronic whiteboard teaching in the stage of basic education. They put forward the interactive electronic whiteboard application reform strategy. These were constructing the community, excavating the effective method, broadening the subject, improving the application level, designing the teaching application and promoting the teaching application. With the development of science and 
technology, the form of reciprocal teaching has been enriched. Educational informatization promotes the innovation of technology-supported reciprocal teaching mode. Foreign scholars have never stopped their researches and explorations of reciprocal teaching mode. According to the relevant foreign literature, the researches on reciprocal teaching mainly focus on these two aspects, the artistic characteristics of reciprocal teaching and the influence of reciprocal teaching on the course. Wassermann Selma (2017), an international expert on classroom interactions, set the stage for the relevance of the interactive teaching method in his book. The book draws from the author's long experience of interactive teaching using the case method rooted in the Harvard. He offered detailed and specific help for teachers who were considering embarking on this approach to teaching. Coverage included teaching to the immense ideas and preparing students. It is based on developing good listening, responding, and questioning skills in an interactive discussion. Mohammad and Abbas (2012) used reciprocal teaching strategies to improve students' reading comprehension to handle students' lower comprehension skill. Reciprocal teaching involved four main metacognitive reading strategies: predicting, questioning, clarifying, and summarizing. They stated relationship between reciprocal teaching and reading comprehension. What's more, they indicated that reciprocal teaching had a significantly positive effect on the English reading comprehension of EFL students.

Reciprocal teaching's effectiveness and influence are beyond doubt. The proper teaching method is one that can stand constant examination. Many scholars at home and abroad have explored the influence of reciprocal teaching on reading ability. The researcher will explore the influence of reciprocal teaching on students' writing ability, and try to analyze the effect of a reasonable reciprocal teaching model based on the production. This will probably provide new practical ideas and research directions to English teachers in Chinese senior high school.

\section{RESEARCH DESIGN}

\section{A. Research Questions}

Based on the purpose of the research, the research aims to answer the following two questions:

(1) What effect does PBRT have on Chinese senior high school students' attitude in English writing?

(2) What effect does PBRT have on Chinese senior high school students' performance in English writing?

\section{B. Research Instruments}

The research instruments include classroom observation, interview and test. Pre-test and pre-interview have been conducted before action research. The whole class, taught by the researcher, participated in the test. Three students A, B and $\mathrm{C}$ of different levels from the class were interviewed. Two rounds of action research have been conducted. There are test and interview at the end of each round. During the action research, the researcher observed her own class and four teachers in the same grade acted as observers to assign points to each item according to the class observation scale. Classroom observation data were tested by SPSS reliability and validity. Through classroom observation data, the researcher explores the change of students' interests in writing. Paired sample tests were conducted to explore whether there were significant differences in test scores between pre-test and post-test.

\section{Research Procedure}

The researcher carried out this research strictly according to the steps of action research. First of all, through daily classroom observation, the researcher had found that there were still some problems in English writing class in Chinese senior high school, such as students' low interests and low class efficiency in writing. Through literature review, the researcher understood the current research on writing classroom. During this period, the researcher focused on the effectiveness of POA and the stimulation of reciprocal teaching. Therefore, the researcher decided to explore the effectiveness of PBRT in senior high school English writing class.

Secondly, the researcher made a research plan and carried out the research in the teaching experiment. The formulation of the research plan included research questions, research subjects and research instruments, as well as two rounds of action research programs. The implementation of action research teaching followed the teaching process of POA and was student-centered. Each round of action research included research plan, research implementation and research reflection.

Finally, the researcher collected and analyzed the research data. After the two rounds of action research, the researcher collected the results of interviews for analysis. The purpose is to investigate whether students could be motivated to learn English writing in PBRT. The results of classroom observation scale and test were analyzed again through SPSS. The data of classroom observation was analyzed whether to stimulate their interests in English writing. The researcher would compare students' writing scores to test whether PBRT can improve students' English writing abilities.

\section{RESULTS AND DISCUSSIONS}

In order to explore the application of PBRT in Chinese senior high school English writing classes, the researcher conducted two rounds of action research. Through classroom observation, interviews and tests, the researcher collected and analyzed data, aiming to explore the influence of PBRT on students' interests and performance in writing. 
Researcher further explored how to construct well PBRT in writing class. The following are research results and discussion.

\section{A. The Influence of PBRT on Students' Writing Performance}

Through testing, the researcher analyzes the influence of PBRT on students' writing scores and explore whether students' writing ability has changed. Before the action research, the researcher conducted a pre-test to understand the students' writing performance. After the first round of the action research, the researcher took a test and compared the results of the test with those of the pre-test. After the second round of the action research, the researcher took another test and compared the results with those after the first round of the action research. The experimental data were analyzed by SPSS.

(1) Comparison of Test Results between Pre-test and the First Round Test

In order to explore the changes of students' writing scores after the first round of action research, the researcher made descriptive statistics between the pre-test scores and the scores after the first round of action research. The result is shown in Table I.

TABLE I

DESCRIPTIVE STATISTICS OF PRE-TEST AND FIRST ROUND TEST

\begin{tabular}{|l|l|l|l|l|}
\hline & $\mathrm{N}$ & Mean & Std. Deviation & Std. Error of Mean \\
\hline Pre-test & 50 & 10.98 & 4.913 & .695 \\
\hline First Round Test & 50 & 12.42 & 4.504 & .637 \\
\hline
\end{tabular}

Statistics show that the average score of the pre-test is 10.98 , and the average score of the test after the first round of action research is $\mathbf{1 2 . 4 2}$. There is a slight difference in the mean value of the two scores. The scores increase slightly after the first round of action research. However, it needs to be further verified by paired sample $\mathrm{T}$ test to explore whether there is a statistically significant difference between them.

TABLE II

PAIRED SAMPLES T-Test (PRE-TEST AND FIRST Round TEST)

\begin{tabular}{|c|c|c|c|c|c|c|c|c|}
\hline & \multicolumn{5}{|c|}{ Paired Differences } & \multirow{3}{*}{$\mathrm{t}$} & \multirow{3}{*}{ df } & \multirow{3}{*}{$\begin{array}{l}\text { Sig. } \\
\text { (2-taile) }\end{array}$} \\
\hline & \multirow{2}{*}{ Mean } & \multirow{2}{*}{ Std. Deviation } & \multirow{2}{*}{$\begin{array}{l}\text { Std. } \\
\text { Mean }\end{array}$} & \multicolumn{2}{|c|}{ 95\% Confidence Interval of the Difference } & & & \\
\hline & & & & Lower & Upper & & & \\
\hline Pre-test \& First round & -1.440 & 1.716 & .243 & -1.928 & -.952 & -5.933 & 49 & .000 \\
\hline
\end{tabular}

Table II shows that, at the significance level of 0.05 , there is a significant difference between the test results after the first round of action research and the pre-test results $(\mathrm{t}=0.00<0.05)$. What's more, the test results after the first round of action research are significantly higher than the pre-test results.

(2) Comparison of Test Results between the First Round Test and the Second Round Test

After the first round of action research, the researcher has reflected on the problems in the research process, and redesigned the second round of action research program. After the second round of action research, the researcher conducts a test to further explore the influence of PBRT on students' writing scores. The test results after the first action research are compared with those after the second action research. The following are the basic quantities that describe the statistics.

TABLE III

DESCRIPTIVE STATISTICS OF FIRST ROUND TEST AND SECOND ROUND TEST

\begin{tabular}{|l|l|l|l|l|}
\hline & N & Mean & Std. Deviation & Std. Error of Mean \\
\hline First Round Test & 50 & 12.42 & 4.504 & .637 \\
\hline Second Round Test & 50 & 14.58 & 3.775 & .534 \\
\hline
\end{tabular}

As can be seen from Table III, the mean test scores after the two rounds of action research are slightly different. The average score after the second action research is 14.28. The average score after the first action research is 12.42 . The average score after the second action research is slightly higher than the first. However, whether there is a statistically significant difference between the two, it needs to be further tested by paired sample $\mathrm{T}$ test. The result of paired sample t-test is shown in Table IV.

TABLE IV

PAIRED SAMPLE T-TEST (FIRST ROUND TEST AND SECOND ROUND TEST)

\begin{tabular}{|c|c|c|c|c|c|c|c|c|c|}
\hline & \multicolumn{6}{|c|}{ Paired Differences } & \multirow{3}{*}{$\mathrm{t}$} & \multirow{3}{*}{ df } & \multirow{3}{*}{$\begin{array}{l}\text { Sig. } \\
\text { (2-taile } \\
\text { ) }\end{array}$} \\
\hline & \multirow{2}{*}{ Mean } & \multirow{2}{*}{ Std. Deviation } & \multirow{2}{*}{$\begin{array}{l}\text { Std. } \\
\text { Mean }\end{array}$} & \multirow[t]{2}{*}{ Error } & \multicolumn{2}{|c|}{ 95\% Confidence Interval of the Difference } & & & \\
\hline & & & & & Lower & Upper & & & \\
\hline $\begin{array}{l}\text { First Round Test \& } \\
\text { Second Round Test }\end{array}$ & 2.160 & 1.822 & .258 & & 1.642 & 2.678 & 8.381 & 49 & .000 \\
\hline
\end{tabular}

The paired sample T-test shows that at the significance level of 0.05 , the sig value of the paired sample T-test between the test scores after the first action research and the second action research is $t=0.000<0.05$. Therefore, the test 
scores after the second round of action research are significantly different from those after the first round of action research. And the test scores after the second round of action research are significantly higher than those after the first round of action research.

Through the analysis of test data by SPSS, it can be seen that the application of PBRT in writing class has significantly improved students' writing performance. Through teaching examples, the researcher collected students' modified model essays. It is clear that the students' writing ability has been significantly improved. First of all, the main points of the composition are complete. Through discussion, students can have something to say about the topics they write about. Students can master the main points of the content, with doing not omit and covering all aspects. Secondly, the language expression is fluent. When writing a composition, students should fully mobilize their knowledge base and use the knowledge they have learned to express their opinions fluently. For the Chinese senior student, the knowledge of attributive clause is not a new knowledge, but a difficult point. During learning writing, students can use attributive sentence pattern correctly. When writing, students can consciously synthesize simple sentences into complex ones. Finally, the logical structure of the article is clear. Students can use vocabulary to express the logic sequence of the passage, for example first of all, what's more, moreover, in addition, at last and so on. At the same time, students master transitional logical words, such as but, however, on the contrary and so on. With these words, the whole article is reasonable, logical and clear. Students can express their ideas with rational thinking. To a certain extent, students have improved in writing ability.

Teachers should promote knowledge application and pay more attention to production during class teaching. Teachers present input materials for students to absorb in class, with the purpose of promoting writing by reading and production of written knowledge. In an efficient class, teachers must pay attention to students' output and make it clear that teaching links and classroom activities are all centered on knowledge output. First of all, before class, teachers should pay attention to the students' previous level of writing and prepare teaching material. Teachers should not only have a strong sense of teaching, but also formulate clear teaching objectives and requirements, according to the students' school age stage. Teachers in mind need consider what to practice in this composition class? What will the students learn from the writing training? Only by thinking clearly about these problems can the teacher grasp the key and prepare the composition class. Secondly, in class, the teacher should find the right breakthrough point in the writing teaching, choose a good road and let the students boldly think by themselves. Teachers guide students to build a knowledge framework, who will learn the content of the systematic through the "scaffolding". In the writing class, the teacher presents the examples to the students. In this stage of learning, teachers should consciously guide the students to summarize the framework of the article. If necessary, students can draw mind maps to help them understand. In the process of learning, students are aware of the fun of learning and enhance their confidence in learning. Moreover, teachers should guide students to contact life and select materials from life. Teachers guide the students to approach the life, observe the life, and experience the emotion. Finally, the important part is the task of production. Students make scaffolding by using their own knowledge base to complete a reasonable text. During this period, students are required to focus on language expression, content points, logical structure and writing. Teachers need to walk around the classroom, help students in need appropriately, and give necessary guidance. For the students whose writing is obviously improper, the teacher should remind them in time so as not to deviate from the meaning of the text. After the students finish the output task, the teacher should make a concise comment to promote the students' writing ability to a higher level.

\section{B. The Influence of PBRT on Students' Writing Attitude}

The researcher uses classroom observation to better explore the influence of PBRT on students' interests in writing. Researcher observes her own class and commissions four teachers of the same grade to conduct classroom observation during the teaching time. Five observers concluding researcher assign points to each item of the class observation scale during the class. After each round of action research, the researcher collects and sorts out the observation scales. In order to make the scale data reliable and effective, the researcher uses SPSS to test the reliability and validity of the data of the classroom observation scale. 
TABLE V

RELIABILITY ANALYSIS

\begin{tabular}{|c|c|c|c|c|c|c|c|}
\hline Dimensionality & Items & $\begin{array}{l}\text { Scale } \\
\text { Mean if } \\
\text { Item } \\
\text { Deleted }\end{array}$ & $\begin{array}{l}\text { Scale } \\
\text { Variance if } \\
\text { Item Deleted }\end{array}$ & $\begin{array}{l}\text { Corrected } \\
\text { Item-Total } \\
\text { Correlation }\end{array}$ & $\begin{array}{l}\text { Squared } \\
\text { Multiple } \\
\text { Correlation }\end{array}$ & $\begin{array}{l}\text { Cronbach's } \\
\text { Alpha if Item } \\
\text { Deleted }\end{array}$ & $\begin{array}{l}\text { Cronbach's } \\
\text { Alpha }\end{array}$ \\
\hline \multirow{5}{*}{ Motivating } & Scene & 10.20 & 10.400 & .580 & .504 & .903 & \multirow{5}{*}{.889} \\
\hline & Attempt & 10.20 & 10.622 & .795 & .762 & .856 & \\
\hline & Assignment & 10.30 & 11.344 & .777 & .866 & .867 & \\
\hline & Discussion & 10.60 & 10.489 & .757 & .580 & .862 & \\
\hline & Sharing & 10.70 & 7.567 & .900 & .936 & .830 & \\
\hline \multirow{4}{*}{ Enabling } & Assignment & 10.30 & 12.456 & .771 & .906 & .913 & \multirow{4}{*}{.923} \\
\hline & Material & 10.60 & 10.489 & .868 & .872 & .893 & \\
\hline & Learning & 10.70 & 12.900 & .832 & .855 & .910 & \\
\hline & Instruction & 10.70 & 11.567 & .771 & .723 & .912 & \\
\hline \multirow{4}{*}{ Assessment } & Sharing & 10.90 & 9.878 & .855 & .935 & .900 & \multirow{4}{*}{.920} \\
\hline & Self & 5.30 & 5.344 & .826 & .685 & .898 & \\
\hline & Peer & 5.20 & 5.733 & .838 & .709 & .884 & \\
\hline & Teacher & 5.30 & 6.011 & .857 & .736 & .872 & \\
\hline
\end{tabular}

Table V shows the reliability test of classroom observation data. As can be seen from the table, the coefficients of Cronbach's are 0.889, 0.923, 0.920 in three dimensions (motivating, enabling and assessment). All of them are greater than 0.6, which proves that the data have good consistency and good overall reliability and pass the test. At the same time, the researcher uses SPSS, factor analysis method, KMO value and Bartlett's Test of Sphericity Approx Chi-square to measure the validity of the scale data. As can be seen from Table VI, the cumulative variance after rotation in three stages are $72.663 \%, 78.480 \%$ and $86.497 \%$ respectively, all greater than 50\%, and the Component Matrixa of each item is over than 0.05 . In addition, the significance probabilities of $0.001,0.000$ and 0.001 are all less than 0.05 , indicating that the original data have a certain correlation. The values of KMO are $0.718,0.682$ and 0.760 respectively, all greater than 0.6 , indicating that the data is valid. The classroom observation scale can be used for classroom observation and its data can be used for analysis and research.

TABLE VI

VALIDITY ANALYSIS

\begin{tabular}{|c|c|c|c|c|c|c|}
\hline & Items & $\begin{array}{l}\text { Component } \\
\text { Matrixa }\end{array}$ & Communalities & KMO & Sig. & Total Variance Explained \\
\hline \multirow{5}{*}{ Motivating } & Scene & .692 & .479 & \multirow{5}{*}{.718} & \multirow{5}{*}{0.001} & \multirow{5}{*}{$72.663 \%$} \\
\hline & Attempt & .878 & .770 & & & \\
\hline & Assignment & .868 & .753 & & & \\
\hline & Discussion & .840 & .705 & & & \\
\hline & Sharing & .962 & 925 & & & \\
\hline \multirow{5}{*}{ Enabling } & Assignment & .837 & .701 & \multirow{5}{*}{.682} & \multirow{5}{*}{0.000} & \multirow{5}{*}{$78.480 \%$} \\
\hline & Material & .926 & 858 & & & \\
\hline & Learning & .892 & .795 & & & \\
\hline & Instruction & 853 & .728 & & & \\
\hline & Sharing & .918 & .842 & & & \\
\hline \multirow{3}{*}{ Assessment } & Self & .922 & .851 & \multirow{3}{*}{.760} & \multirow{3}{*}{0.001} & \multirow{3}{*}{$86.497 \%$} \\
\hline & Peer & .929 & .864 & & & \\
\hline & Teacher & .938 & .880 & & & \\
\hline
\end{tabular}

Before the action research began, the researcher has conducted achievement tests and interviews. The researcher learns that the writing scores of students are very low. Some students think writing is boredom, or even disgust. Some students have nothing to do in the writing class without thinking, discussing and writing. After two rounds of action researches, through the feedback data of observers, the researcher has found that students participate in writing class more and more actively. Students also try their best to product tasks. There is a positive change in the students' attitude towards writing.

In the first round of action research, students' learning enthusiasm and interests in writing improved slightly. In the motivating stage, the researcher presents close to real teaching situation to stimulate students' interests. Some of the students with good grades have showed great enthusiasm in writing and taken the initiative to participate in group discussions and actively tried to output tasks. However, some students at the lower level are dull in class, unwilling to participate in group activities. If they do participate in group activities, they chat with their peers. These students do not attempt to complete task. In the enabling stage, the researcher presents input materials and students conduct selective learning. Students' classroom performance is also a bipolar phenomenon. On the one hand, some students actively absorb input materials, selectively record key points, and accumulate material for their own writing. On the other hand, some students have difficulty accepting input material, can't distinguish the key points, and do nothing in class. In the assessment stage, the advanced students actively participate in the evaluation and are more interested in class. And the poor students in studying, to participate in the evaluation is very slack. In class, the students are slightly active, and overall they are not very active. In the first round of action research, the design idea is not yet mature. The selection of 
input materials fails to mobilize students' enthusiasm well. There is less time for group discussion and sharing, resulting in lack of communication among students. After the first round of action research, the researcher reflected and conducted second round of action research.

In the second round of action research, students' enthusiasm in class and interests in writing were greatly improved. In the motivating stage, the researcher starts from the focus of social issues and shifts from the focus to familiar situations around them. This greatly attracts students' interests in learning. Every student vied with each other to express his or her opinion on the social focus issue. In the group discussion, each student has something to say and takes good care of the weaker students. In the enabling stage, the researcher presents input materials on the PPT to facilitate students' memory. The researcher guides the students to summarize the key words, phrases, sentence patterns and logical structure of the article independently. Students at this stage will have a sense of achievement so as to stimulate the motivation of learning. In the assessment stage, interactive multi-evaluation is adopted in the classroom. Students change their identities and become "little teachers" and make comments on their peers" compositions. The composition interchange corrects the error-type question. The students learn not only the writing, but the multi-faceted question type study. In this way, students can pay more attention to their mistakes in writing and correct them effectively.

Teachers should pay different attention to students at different levels. Teachers should build a student-oriented and teacher-led classroom. At present, the mainstream idea of education is to highlight the dominant position of students, in order to change the traditional teaching mode of "filling the classroom", so that students can participate in the teaching. "Community" is composed of students and teachers to promote the growth of all members as the goal, emphasizing the process of learning with the interaction of learning concept as the guidance, through mutual communication. Compared with the traditional teaching mode, the biggest characteristic of this mode is to emphasize the communication and interaction between teachers and students, so as to play a collective dynamic role in teaching. The following points should be achieved in constructing the teacher-student community.

First, teachers should bear intellectual authority. One of the purposes of teaching is to let the students acquire knowledge. As the saying that, to make iron needs own hard. Teachers should have enough knowledge base. In this way, teachers can establish knowledge authority in the hearts of students. If teachers fail to establish the authority of knowledge, the status of teachers in the hearts of students will plummet, which will greatly affect the teaching efficiency of teachers. In the construction of the teacher-student community, teachers will encounter sudden problems at any time. At this time, teachers need to show their educational wit. If the teacher doesn't have a jar of water, how can he scoop out a bowl of water for the students? Therefore, teachers should continue to learn after class, constantly improve themselves, so as to set up their own knowledge authority in class. Then they can build a harmonious teacher-student community under the high mountains of students. Second, it requires equal and harmonious teacher-student relationship. Democracy and equality are not only the need of the trend of democracy in modern society, but also the direct demand of humanism in teaching life and the concrete embodiment of modern personality. It requires teachers to understand students, exert non-power influence and communicate with all students equally. At the same time, it requires students to express their own thoughts and behaviors correctly, learn to cooperate and learn together. Modern education idea advocates "Teachers are not only experts but also friends in harmonious relations". After all, every student has own thinking, feeling from person to person. Everyone hopes to get the teacher's respect and understanding. It is an important state of equality between teachers and students. Only in this way, can the relationship between teachers and students be more harmonious, and further promote the construction of community of teachers and students. Third, it also needs enough communication activities. One of the cores of the teacher-student community is the interaction between teachers and students. Only with sufficient exchanges and activities can the information between teachers and students be circulated. Teachers and students generate resonance, and promote the construction of the teacher-student community. Through communication, teachers can better understand students' learning situation, and then design more effective activities to help students improve their abilities. The construction of a harmonious community can't just stay in the classroom, but extra-curricular activities. The current classroom interaction is more focused on language communication, which is somewhat monotonous. So teachers and students promote interaction frequency in extra-curricular activities. Extracurricular communication activities play a positive role in promoting the construction of a harmonious teacher-student community, so it is also a way that teachers can actively try.

The research also analyzes students' attitude through interview. One purpose of the pre-interview is to understand the students' difficulties they encountered in the process of learning English writing. The other purpose is to know students about their participation in classroom activities. It can be seen from the data of pre-interview that the difficulties encountered by students in the process of English writing are mainly manifested in vocabulary, sentence pattern and structure. First, students lack the accumulation of vocabulary. Students usually accumulate less vocabulary. Students can't think of corresponding English expressions when they are writing. As student C says, his head is empty when he writes. Students should make good use of their time to accumulate vocabulary. In this way a full mind has material to output when writing. Second, students have difficulty mastering sentence patterns, especially advanced ones. Both student A and student B have mentioned that the sentence structure was not clear when writing. The article is dominated by simple sentences and lacks advanced sentence patterns, such as attributive clauses. Students make mistakes when they use attributive clauses. In order to make the sentence patterns varied, students should learn the grammar of sentence patterns well in daily life. Third, students lack attention to the logical relation words. When students write 
sentences, they tend to ignore the connection between sentences. The result is what Student B calls a "running account." Therefore, students should pay attention to sentence cohesion when learning to read texts. The teacher should highlight the relative words when necessary. Students have not great interests in participating class. There are two main reasons. One reason is the influence of students own factors, the other reason is affected by students around. Because of their poor English knowledge, students are unable to participate in classroom activities. As student C said, "I don't understand vocabulary, grammar or sentence structure. So I'm usually more of a spectator." Students lack self-confidence and are afraid of making mistakes in class. This kind of student is often a listener in class. For Student B, he doesn't like to express his own ideas and prefers to listen to others. Students are easily influenced by the classmates around them. Just like the case of student A, if the classmates around him don't answer the question, he will feel embarrassed to participate in the interaction. Students' classroom performance is greatly influenced by the environment around them. Teachers should help students build up their self-confidence so that they can actively participate in class activities.

After the first round of action research, the researcher conducted an interview. The purpose is to understand the progress of students' English writing, class participation and the effectiveness of the writing classroom model. Students have made a certain progress in English writing. The vocabulary used in composition is more precise than before. Students are able to use sentence patterns and connectives correctly to ensure fluency and coherence. Student A has mentioned, "The improvement of my English performance is mainly reflected in the following aspects: first, writing time is shorter; second, writing ideas are clearer; third, some complex structures are more freely used in writing. Compared with before, they are used more flexibly." Student B said, "My writing scores have improved significantly, about five points higher than before. I use some words to express the transition, so the article structure is more compact." Student $\mathrm{C}$ has said, "My English writing score is much better than before. The main improvement is that I have something to write, or at least I can link it together into a complete sentence." As for the participation in classroom activities, students showed a more positive attitude. During the interview, students would use some positive words to express themselves, such as "would rather", "would like to", "want" and so on. From the students' words, the author can see the students' desire to take an active part in class activities. Students reflected under PBRT classroom mode, the classroom atmosphere is relaxed, the classroom situation is real, and the classroom activities are interesting. This is very important for students to learn and master knowledge.

After the second round of action research, the researcher continued to pay attention to student progress and class participation, as well as to further understand the improvement of the PBRT classroom model. The researcher did an interview again after the second round of action research. According to the interview data, students have made great progress in English writing after four months of research. Students use vocabulary more accurately and freely. Sentence structure is smoother and more compact. Students responded well, such as "improved grades", "more comfortable sentence patterns", "advanced sentence patterns" and "complete sentences", etc. Students are more active in class activities. The interviews with students mentioned many positive words, such as "be willing to", "very like", "would like to" and so on. Students generally show preference to the current classroom atmosphere. Student A thinks that this class mode will not feel pressure and embarrassment, and hopes to continue to use it. Student B said, "The classroom atmosphere is not as depressing as before. Most of the time, the initiative to learn is in your own hands. I am also willing to learn. Learning enthusiasm is very high. I hope this teaching mode can continue to be used in future writing teaching." Student C thinks the classroom atmosphere is very relaxed. Studying in this atmosphere, He won't have a lot of pressure. In class, he wants to participate in activities and discuss with group members. He can also learn some words and phrases from his classmates, which is very helpful for him to write a composition. In addition, student $\mathrm{C}$ expresses his hope to set writing tasks of different difficulty.

Real and interesting teaching situations can bring students into the classroom and catch their eyes. So it is very important to design an effective teaching situation. Firstly, the teaching scene should be conducive to stimulating students' thirst for knowledge. Teachers should create a cognitive conflict between teaching content and students' psychology of seeking knowledge so as to trigger students' urgent desire to make clear the unknown. In addition, teachers make the teaching process based on the psychological basis of students' willing to learn, and promote teaching layer by layer. In this way, students have great interests in learning. Therefore, the teaching situation should be able to stimulate thinking and interesting, so as to stimulate students' thirst for knowledge. Gradually students will be full of interests in the upcoming teaching content and desire to learn. Secondly, the teaching scene should choose the content and way that the student is willing to accept. The teaching scene should choose the content and method that the students fit. The teaching situation should choose the content and method that the students are suitable for, such as body language, partner sharing and so on. In this way, the content of the activity can be fully served for teaching and achieve the best effect. In such a teaching situation, students can easily grasp the teaching content. Students in the completion of learning tasks not only taste the joy of success, but also constantly mobilize the enthusiasm of students to practice. Thirdly, the teaching situation should make the teacher's teaching serve the student's learning. In order to make the teaching scene guide the students' studying, the teaching scene should be conducive to the transformation of teachers' main teaching function into service function. The teaching strategy of learning before teaching has been widely adopted by many teachers. The position of teachers has gradually shifted from the front of the stage to the back of the students. It is a mainstream thinking that teaching serves learning. As the saying goes, "Lookers-on see most of the game". 
Students in their own exploration or cooperative learning, teachers are not idle. The teacher should actively look, listen and attentively feel the students' spiritual world. Even at any time, the teacher can grasp, analyze the various information in the classroom with timely and effective guidance. What's more, the teacher should pay attention to giving systematic guidance. The teacher's help is not interference, not to replace, but a kind of heuristic guidance.

According to the interview, to some extent, the application of PBRT in English writing classes in Chinese senior high school has improved students' interests in writing. After four months of practical application, the researcher has found that students' attitudes towards English writing have improved. Students mobilize the enthusiasm of learning through classroom activities. After group discussion, students can broaden their ideas. Practice has proved that the application of PBRT in English writing class can effectively change students' attitudes towards English writing and enhance their interests in writing. When teachers apply PBRT in practice, they should design various classroom activities. First of all, teachers should design the teaching situation close to the reality. Students are able to give specific suggestions and ideas in the context. Secondly, teachers should give students enough time to have group discussion. Students actively participate in the discussion and learn from each other during the discussion. Then, the teacher should present the input material that is a little more difficult for the student and clearly describe the output task to the student. Students selectively study texts and eventually form their own knowledge. Finally, teachers should enrich the ways of composition evaluation. Students realize their mistakes in self-evaluation and mutual evaluation, and notice their mistakes in question-type interaction. It is a long way from the effective use of PBRT in English writing class. In the future, more researchers need to practice and reflect.

\section{CONCLUSION}

\section{A. Research Findings}

The researcher chooses her own class as research object, so the action research has certain practical significance. This research has some implications for English writing teaching in Chinese senior high school. Firstly, through two rounds of action research, the researcher finds that PBRT can be effectively applied to English writing classes in Chinese senior high school. The results show that PBRT can effectively enhance students' interests in English writing and improve their attitudes towards English writing class. Moreover, the students have significantly improved in English writing performance. In addition, the language expression and logical cohesion of the article have been greatly improved. Secondly, teachers should strengthen their professional development. Teachers should design real situation and promote knowledge application. Teachers should organize teaching effectively and improve class efficiency. Teachers should continue to learn and further research their studies, through education, training and other forms, so that their professional ideals, ethics and knowledge and skills can keep pace with the Times. In practice teaching, teaching adopts the method of theoretical learning, trying to practice, and repeated inquiry to constantly update and expand teaching skills. Thirdly, teachers should set up a correct view of students and build a student-oriented and teacher-led classroom. Teachers design realistic teaching situations based on students' cognitive development to arouse students' attention and thinking. Teachers then think deeply and organize the interesting teaching creatively. In this way, it will make teaching form diversification and raise the student's enthusiasm. In addition, teachers should teach students at different levels according to their aptitude. This requires teachers to carefully spot the differences of students. In view of the differences of students, teachers find relevant data to analyze the reasons, so as to implement the teaching. For students, students should take the initiative to absorb internalized knowledge to achieve a good output effect. In this process, the teacher should do a good job as the guide, do not interfere with students' production too much, but be appropriate to remind and guide. Last but not least, it is important to be a teacher as well as a researcher. Teachers should cultivate the awareness and ability to study the educational objects and educational problems. Only by insight into educational problems, deep reflection and exploration, can a teacher become a research-oriented teacher, who can find problems and try to solve them. For example, in the writing class, students generally have low interest in learning. Teachers should find out the problems, put forward solutions to the problems, and then conduct practical research and verify them to form mature opinions. Only in this way can teachers improve their teaching methods and make continuous progress in professional development.

It is inevitable that teachers will encounter some teaching problems in English teaching. PBRT provides many teachers with a new way to solve the problems. Teaching is a bilateral activity that consists of teachers' teaching and students' learning to pass on and master social experience. Therefore, in the course of teaching, teachers should pay close attention to teaching and learning, and make them fit together through effective teaching organization activities. Here, the researcher appeals to the majority of teachers to do a research-oriented teacher. In the process of teaching insight into educational issues, conduct in-depth research, so as to improve the effectiveness of teaching and personal professional development.

\section{B. Pedagogical Implications}

As a preliminary attempt to apply PBRT to Chinese senior high school English writing teaching, the researcher has conducted two rounds of action research for four months. The researcher has found that the results are basically consistent with expectations. However, due to the limited professional knowledge of the researcher and the influence of objective factors, there are still some deficiencies and limitations in this research, which cannot be ignored. Firstly, the research 
sample is much limited. In this research, the researcher selected 50 students who are taught by herself as research objects of this study. The research sample is small and not universal. At the same time, it cannot guarantee the representativeness of samples. So the results of the experiment remain to be tested. Secondly, this action research only has lasted for 16 weeks, lacking long-term research. As is known to all, English teaching is a long-term process. And students' writing ability also needs long-term learning and accumulation to form. The improvement of students' writing ability also needs to go through a long process. There is not enough time to test the effect of PBRT in this research. The researcher can only analyze the research based on the two rounds research data. Therefore, the researcher does not have more time to collect and analyze data for research. Thirdly, the teacher's subjectivity is stronger when judging the result. Teachers are often influenced by subjective factors when marking compositions. In this research, the scores of students' compositions are all judged by teachers personally according to the Grading Standards for English Composition in Chinese senior high school. Teachers are highly subjective when assigning scores. It is a drawback of the research. This factor is difficult to overcome and inevitable.

\section{REFERENCES}

[1] Alister Cumming. (2017). Research and Design of Production-oriented Approach. Chinese Journal of Applied Linguistics 40(04):459-463.

[2] Charlene Polio. (2017). Reflections on the Production-Oriented Approach vis-à-vis Pre-service Teachers. Chinese Journal of Applied Linguistics 40(4): 464-467.

[3] He Ying. (2020). Research on Curriculum Design Based on POA. Proceedings of the 2020 South China World Expo Academic Symposium (I) (pp.888-891).

[4] Krashen, S. (1985). The Input Hypothesis: Issues and Implications. New York: Longman.

[5] Li Bingde. (2003). Teaching Theory. Beijing: People's Education Press.

[6] Mohammad Reza Ahmadi \& Abbas Pourhossein Gilakjani. (2012). Reciprocal Teaching Strategies and Their Impacts on English Reading Comprehension. Theory and Practice in Language Studies 2(10): 2053-2060.

[7] Palincsar, A. S. \& Brown, A. L. (1984). Reciprocal teaching of comprehension-fostering and comprehension-monitoring activities. Cognition and Instruction (1):117-175.

[8] Rod Ellis. (2017). The Production-Oriented Approach: Moving Forward. Chinese Journal of Applied Linguistics 40(4): 454-458.

[9] Sun Shuguang. (2020). An Analysis of the Principles of Teacher-Student Cooperation Evaluation in POA. Frontiers of Foreign Language Education Research 3(02): 20-27+90-91.

[10] Swain, M. (1985). Communicative Competence: Some Roles of Comprehensible Input and Comprehensible Output in Its Development. Rowley, MA: Newbury House.

[11] Tang Meihua. (2020). A comparison between POA and TBLT: Case Study of Intensive Reading Course Unit Teaching Design for English Majors. Foreign language teaching 41(01): 65-69.

[12] Wassermann Selma. (2017). The Art of Interactive Teaching: Listening, Responding, Questioning. London: Taylor and Francis.

[13] Wen Qiufang \& Sun Shuguang. (2020). An Analysis of POA Scenic Design Elements. Frontiers of Foreign Language Education Research 3(02):4-11+90.

[14] Wen Qiufang. (2008). Output-driven hypothesis and curriculum reform for English majors. Foreign Language Community (02): $2-9$.

[15] Wen Qiufang. (2014). The Output Driven-Input Enabler Hypothesis: An Attempt to Build a Theory of College Foreign Language Classroom Teaching. Foreign Language Education in China (2): 3-12.

[16] Wen Qiufang. (2015). Constructing the Theory System of "Production-oriented Approach". Foreign Language Education and Research (4): 547-558.

[17] Wen Qiufang. (2017). Chinese characteristics of "Production-oriented Approach". Modern foreign languages (3): 348-358.

[18] Wen Qiufang. (2020). Reinterpretation of POA Teaching Process. Frontiers of Foreign Language Education Research (2): 3-3.

[19] Yang Bin \& Ren Xinying. (2014). Research on the application status and development of interactive electronic whiteboard in elementary education. Research on Audio-visual Education 35(06): 71-77.

[20] Yang Tianjiao. (2017). New Measures in the New Era -- On the Innovative Theory System of Foreign Language Education with Chinese Characteristics (POA). Proceedings of the Third Prize of Excellent Papers of 2017 Academic Annual Conference of Liaoning Higher Education Association (pp.573-580).

[21] Zhang Wenjuan. (2017). An Action Study on the Application of Output-Oriented Approach to College English Teaching. Beijing Foreign Studies University.

Guobing Liu was born in Henan, China. He received the master's degree in corpus linguistics in 2005. Now he is an EFL teacher at the Faculty of International Studies, Henan Normal University. He received the doctoral degree in corpus linguistics and computational linguistics in 2013. In recent years, he published several books and more than thirty academic papers in the key journals both home and abroad. His academic interests include corpus linguistics and foreign language teaching.

Hui Cao was born in Henan, China. She will receive the master's degree of education in 2021. Now she studies at the Faculty of International Studies, Henan Normal University. She is interested in English teaching and her master's thesis is also related to it. 